糖尿病, 尿崩症, Kleine-Levin症候群を

\title{
合併したLaurence-Moon-Biedl症候群
}

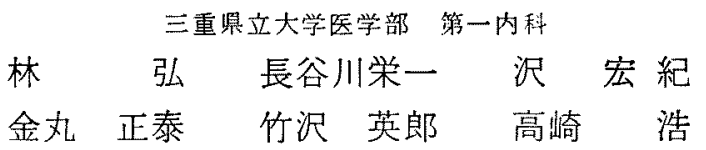

\section{A CASE OF LAURENCE-MOON-BIEDL SYNDROME, COMPLICATED WITH DIABETES MELLITUS, DIABETES INSIPIDUS AND KLEINE-LEVIN SYNDROME}

Hiroshi Hayashi, Eiichi Hasegawa, Hiroki Sawa, Masayasu Kanamaru, Hideo Takesawa and Hiroshi Takasaki

The First Division of Internal Medicine, Mie Prefectural University, School of Medicine (Prof. H. Takasaki)

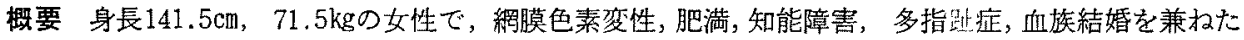
Laurence-Moon-Biedl症侯群に棓㽷病および 尿崩症を合併した症例を経駼したが，この症例で，狂暴 性，旣眠発作，脳波のalpha波消失，I $Q=27$ を認めた。 また，metyrapone，ACTHに対し，下垂体， 副筩は正常に反応，トルコ鞍も正常であつた，糖尿病がinsulinでュントロールされ，耐糖能も正常化 されると，同時に，低張尿，多尿 $(6 \sim 8 l)$ ，口渴が双られ，Pitressinテスト，Carter-Robbinsテスト，

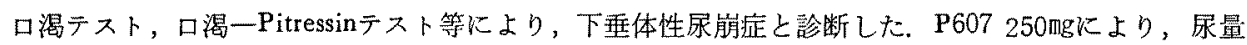
は減少したが， thiazide利屎薬は無效であつた. Laurence-Moon-Biedl症候群の原因は不明であるが， 糖疗病，尿崩症，狂暴性や喈眠発作等のKleine-Levin症候群を合併し，これらの合併症があつたとこ ろから，一連の広範な間脳障害または，発青異常により生じたものと考えた。
\end{abstract}

\section{緒言}

Laurence-Moon-Biedl症候群は，肥満，網膜色 素変性, 知能障害, 性器発育不全, 多指趾症を主 徵とする比較的稀な遺伝性疾患である.1866年， Laurence とMoon ${ }^{1)}$ は，一家族内に肥満，性器発育 不全，網膜色素変性扣よび知能障害を伴う4例を 報告しているが，さらに，1920年にBardet ${ }^{2)}$ が， 1922年にBiedl' ${ }^{3}$ が，それぞれ，指趾過多を伴ら症

[昭和 47 年 7 月 5 日受稿]

本諭文の要旨は，昭和47年 6 月24日行なわれた，第 97回内科学会東海地方会にて発表した。
例の追加を行ない，この様な一連の症候を有する Њのを, 現在, Laurence-Moon-(Bardet)-Biedl症 候群（以下，L-M-B应候群）上称するに至つてい 古。

最近，著者らは，網膜色素変性，肥満，知能 障害，多指趾症，血族結婚などの5主徽を伴つた L-M-B症候群に，糖尿病を合併し，後に，多尿， 低張尿，口渴等の尿崩症状態が顕著とないた稀な 症例を経験したので報告し，若干の文献的考察を 加壳てみた。

\section{定例}




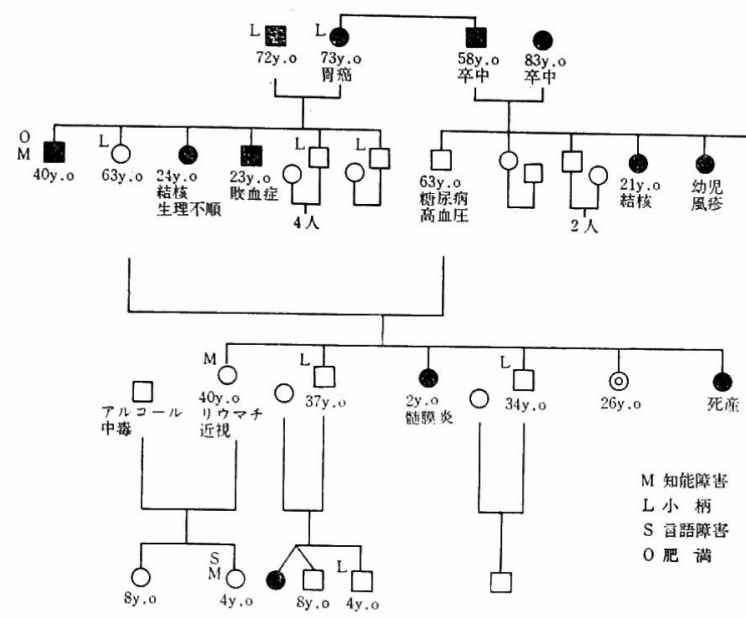

因 1. Family-tree

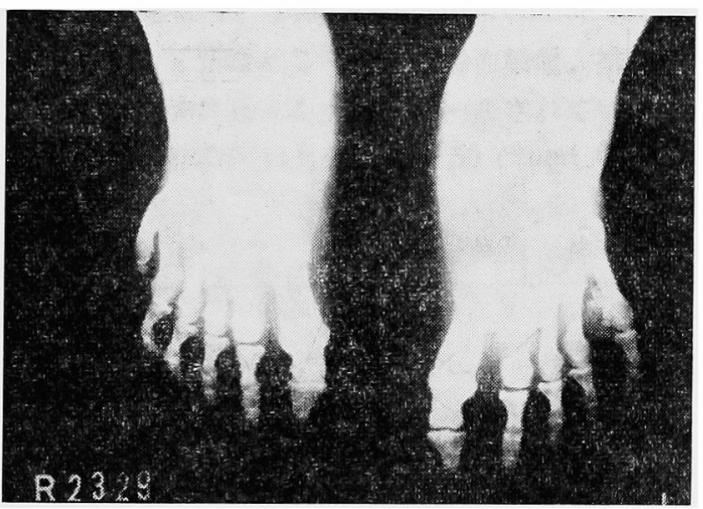

写真 1

患者：26才の女.

家族歴：本症例の両親は, 図 1 亿示寸様に, 従兄妹同志の結婚で，その家族内に，典型的な L-M-B症候群は，見当たらないが，父は，糖尿病 と高血圧症に罹患し, 母方の叔父に肥満と知能障 害を伴うものがあり，また，姉に知能障害がみら れる。

現病歴：満期安産であるが, 生後, 写真 1 の 様に, 両足外側の第 6 趾を認め, 切断手術を受け ている. 歩行開始は，2才であつたが，精神的， 身体的発育遅延があり，7才頃より肥満が著明と なり，9才頃より, 夜盲, 先天的視神経萎縮を指 摘されている，また，10才頃迄，よく全身㾏挛を

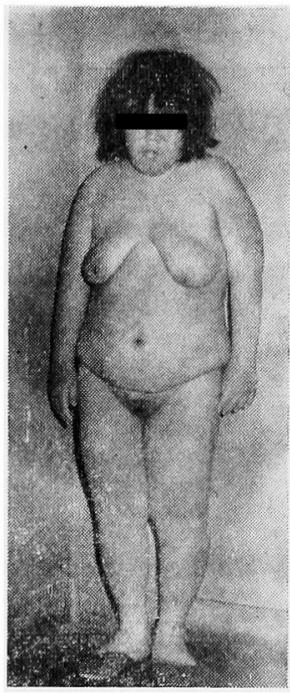

写真 2

起こしたことがあり，学業成績も著しく不良であ つたと言う．初潮は17才で，以後は順調であつた が，22才頃に糖尿を指摘されている，精査の目的 で, 昭和 46 年 2 月, 当内科へ入院.

入院時所見：身長 $141.5 \mathrm{~cm}$, 体重 $71.5 \mathrm{~kg}$ で肥 満度+72\%である．頭部は塔状様で，顔面は，無 欲状であり，全身，とくに, 肩部, 下腹部, 殿部, 大 腿部には，皮覤伸展線が認められ，両足趾外側に は，手術痕が認められる. 胸部には，理学的に特 記すべき所見はなく，肝脾腫を触知しない。その 他, 膝蓋反射も正常で, 病的反射は見られない，乳 房，恥毛，腋毛の発育も正常である，感情は，鈍 であるが,時に反抗的となり,動作は緩慢である.

入院時検査所見：末梢血液で, 貧血は認めら れないが，白血球数は， $10,900 / \mathrm{mm}^{3}$ と増加を認 めた．当時， $39^{\circ} \sim 40^{\circ} \mathrm{C}$ 発熱があり，気管支肺 炎の合併が考えられた。

尿検査では，糖陽性. 比重1045であつたが，ヶ トン体その他，異常所見は，証明されなかつた。

血液生化学検査では, 表 1 の様に, 中性脂肪 $192 \mathrm{mg} / \mathrm{dl}$ と高值を示す以外に特記すべき所見がな かった. $50 \mathrm{~g}$ oral G T T では，空腹時血糖 32 g $\mathrm{mg} / \mathrm{dl}, 60$ 分值 $447 \mathrm{mg} / \mathrm{dl}, 90$ 分值 $504 \mathrm{mg} / \mathrm{dl}, 120$ 分 
表 1 . 入院時検查所見

\begin{tabular}{|c|c|c|c|}
\hline \multicolumn{4}{|c|}{$\begin{array}{l}\text { WBC } 10900 / \mathrm{mm}^{3} \text { (fever) } \\
\text { Hb } 99 \% \text { Hct } 47 \%\end{array}$} \\
\hline \multicolumn{4}{|c|}{ 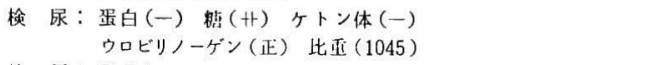 } \\
\hline \multicolumn{4}{|c|}{$\begin{array}{l}\text { 榆 便：舆常なし } \\
\text { 向液生化学検查 }\end{array}$} \\
\hline 総蛋白 & $7.5 \mathrm{~g} / \mathrm{dl}$ & 中性脂䏳 & $192 \mathrm{mg} / \mathrm{dl}$ \\
\hline $\mathrm{A} / \mathrm{G}$ & 1.3 & $\mathrm{Na}$ & $131 \mathrm{mEq} / \ell$ \\
\hline GP T & 37 监位 & K & $4.0 \mathrm{mEq} / \ell$ \\
\hline GOT & 35 単位. & 血清鉄 & $95 r / d 1$ \\
\hline alk-P-ase & $2.2 \mathrm{~B}$ 归位 & 空腹時 ff́l楼 & $277 \mathrm{mg} / \mathrm{dl}$ \\
\hline コリンエステラーゼ & $1.0 \Delta \mathrm{pH}$ & $50 \mathrm{~g}$ G T T & \\
\hline L D H & 290 単位. & 前 & $329 \mathrm{mg} / \mathrm{dl}$ \\
\hline B U N & $11 \mathrm{mg} / \mathrm{dl}$ & 30 分 & $404 \mathrm{mg} / \mathrm{dl}$ \\
\hline クレアチニン & $1.1 \mathrm{mg} / \mathrm{dl}$ & 60 分 & $447 \mathrm{mg} / \mathrm{dl}$ \\
\hline 尿酸 & $6.1 \mathrm{mg} / \mathrm{dl}$ & 90 行 & $504 \mathrm{sg} / \mathrm{dl}$ \\
\hline 総コレステロール & $222 \mathrm{zz} / \mathrm{dl}$ & 120 分 & $484 \mathrm{mg} / \mathrm{dl}$ \\
\hline エステル型 & $172 \mathrm{mg} / \mathrm{dl}$ & 180 分 & $464 \mathrm{mg} / \mathrm{dl}$ \\
\hline 燐胧梊 & $200 \mathrm{mg} / \mathrm{dl}$ & 尿橉 & $60 \sim 80 \mathrm{~g} /$ day \\
\hline
\end{tabular}

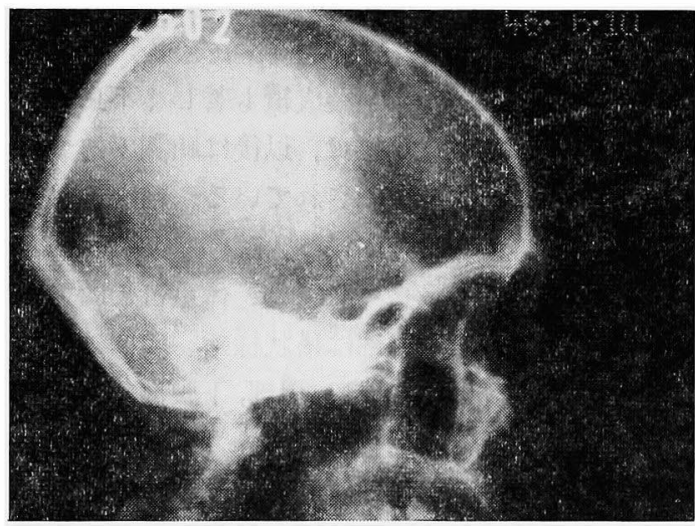

写真 3

值 $484 \mathrm{mg} / \mathrm{dl}$ で明らかな糖尿病型曲線を示した。す た，当時の 1 日排糖量は，60〜80 g に達してい た. 眼科受診の結果では，典型的な網膜色素変性 と左右の視野狭窄が認められた. 一方，トルコ鞍 は，写真 3 の様に正常で破壊像は見られず，心電 図，下熱後の胸部写真もともに，異常所見を認め なかつた。

内分泌学的検査は，表 2 に示す様に，甲状腺機 能は，正常であつたが，尿中ホルモン，とくに， 尿中estrogenが全体に高値を示していた。 また，尿 中17-OHCSは，入院時，高值を示していたが. 以 後, 数回行なつた検査では, 正常に復していた。
表 2. 内分泌学的検査所見 1

\begin{tabular}{|c|c|}
\hline 191 I Taトリオソルブ & $32.3 \sim 27.7 \%$ \\
\hline P B I & $4.2 \sim 6.0 \mathrm{r} / \mathrm{dl}$ \\
\hline B M R & $+6 \sim-2 \%$ \\
\hline \multicolumn{2}{|l|}{ 尿中ホルモン } \\
\hline $17-\mathrm{KS}$ & $6.13 \sim 7.65 \mathrm{mg} /$ day \\
\hline $17-\mathrm{OHCS}$ & $10.0 \sim 15.70 \mathrm{mg} / \mathrm{day}$ \\
\hline Adrenalin & $5 \mathrm{mcm} /$ day $(2 \sim 50)$ \\
\hline Nor-adrenalin & $25 \mathrm{mcm} /$ day $(6 \sim 150)$ \\
\hline Estrone & $7.0 \mathrm{mcm} /$ day $(3 \sim 8.2)$ \\
\hline Estriol & $14.1 \mathrm{mcm} /$ day $(0.8 \sim 1.1)$ \\
\hline Estradiol & $1.6 \mathrm{mcm} / \mathrm{day}(0 \sim 0.3)$ \\
\hline Aldosterone & $7.6 \mathrm{mcm} /$ day $(2 \sim 15)$ \\
\hline 基礎体温 & 一相性曲線 \\
\hline \multicolumn{2}{|c|}{ 精神神経学的検查所見 } \\
\hline \multicolumn{2}{|c|}{ 心理テスト } \\
\hline Tanaka-Benet テスト & $I Q=27$ \\
\hline Benden-G テスト & 明瞭な器犋的障害 \\
\hline \multicolumn{2}{|c|}{ 脱诐 } \\
\hline \multicolumn{2}{|c|}{$\alpha$ 波なく平坦で基線の動摇のみ } \\
\hline
\end{tabular}
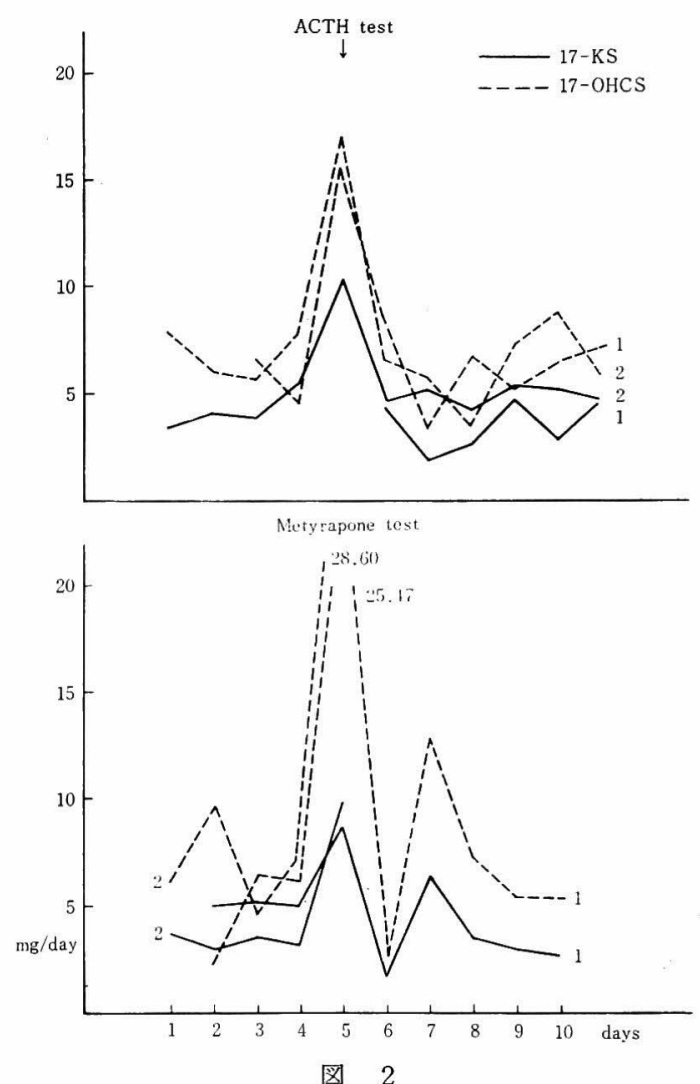

た，2回，行なつた尿中ホルモンの17-OHCS，17KSを指標とするACTHテスト, metyraponeテ 
ストは図 2 の様に，正常反応を示した．精神神経

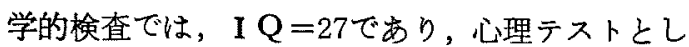
てのBenden-Gテストに括いては器質的障害が認 められた．脳波検査でalpha波は認められず平坦 であつたが，基線の動摇が認められ，paroxysmal にrhythmicalなdelta波が出現していた。

入院後の程過：入院後, 間もなく, 気管支肺 炎を併発したが，強力な抗生物質の使用により， 緩解をみたので, 内科的には, 専ら, 総カロリー を1，800Calの食餌制限とし，頭初，regular-insulin 40 単位より開始したが，7月中旬にはNPH insulin 12 単位の使用で, 空腹時血糖值は80 mg/dl, 尿 糖陰性化なとを認める程に糖代謝異常は，改善さ れた. また，50 g oral GTTでも著明な改善が見 られた。 そこで, insulinをacetohexamide $500 \mathrm{mg}$ に切り換えて見たところ，空腹時血糖值，排糖量 から見て，な拉，よくコントロールされている栐 に思われたので，11月初旬に，50g oral GTTを

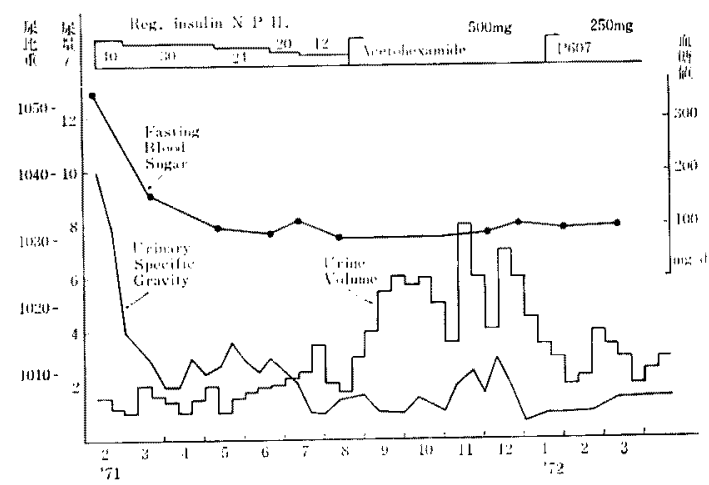

图 3.入院後の経過

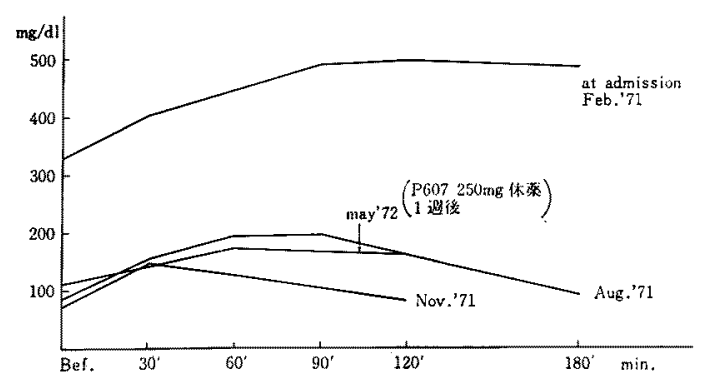

図 4. Changes in $50 \mathrm{~g}$ oral glucose tolerance test.
施行してみたところ, 糖尿病型パターンは認めら れなかつた. しかし, この頃, 患者に反抗性, 狂 暴性の傾向がみられる様になつたため，精神神経 科に転科せしめた。転科後, 精神安定薬の使用の みで，感情は落ち着いていたのであるが，なお， 時儿, 狂暴性, 放浪癖, 反抗性括よび喏服発作等 を示していた．他方，糖尿病状態がコントロール されはじめた 6 月末頃から, 息者は, 多领, 多尿 を訴光始め，9月に入つてからは，尿量は，時 に，6〜8lに達し，尿比重は，1002 1008と低 值を示していた，しかし，はじめ9月湏は，この ような症状を訴え始めたのが夏期であり，心因性 要素が多分に関与しているのではないかと考党て いたが，念のため，下垂体後葉機能検查を行なつ てみた。

Pitressinテストでは, 油性Pitressin tannateの 5 単位の筋注で著明な尿量減少と尿比重の上昇が みとめられ，脳下垂体性尿崩症の像を思わしぬた が，Carter-Robbinsテストでは，2.5\%の 食塩水 $500 \mathrm{ml}$ 点滴静注後の尿量減少は, 見られなか つた。他方，腎㙨能検查としてのP S P 検查で

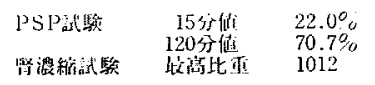

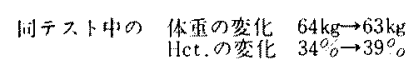

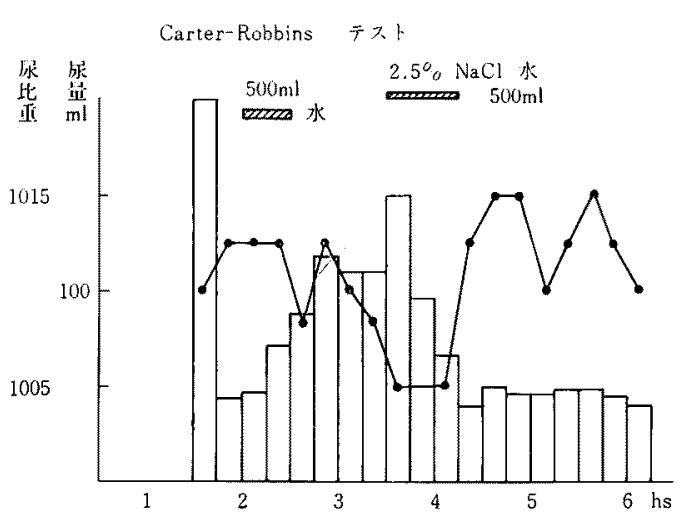


は，一応，督機能は，正常に保たれていたが，腎 濃縮試験においては，最高尿比重は，1012kとど まり，この検查の前後に打いて，体重は，64kgか ら63kgへ減少した。 また，へマトクリット值は， $34 \%$ か $39 \%$ 一濃縮された。この為，昭和 47 年 1 月中旬より，acetohexamide 500 mg $\mathrm{P} 607250 \mathrm{mg}$ にきりかえたところ，原量は，減少して，2〜 $3 l$ に落ち着き，血糖值も安定し，低血精等の副 作用むなく，順調な経過を示した。しかし，この 尿崩症状態は，下金体性，心因性のいずれと決 定し難く，口渴テストと油性Pitressin tannateの 筋注によるPitressinテストとを組み合わせた試験 を行なつてみたところ，口渴テスト後の尿比重 は, 1010, Pitressinテスト後の尿比重は，1020と 明らかに上昇し，下垂体性尿崩症であることが考 えられた。しかし，P607に， thiazide系利尿薬を 加えてみたところ，尿量の減少，尿此重の上昇が 見られなかった，一方P607休楽倦，1 週間，経過 した時点での50g oral GTTは，再度，糖尿病型 を示していた。

\section{考案 \\ L-M-B症候群について}

本症候群は，1866年，Laurence とMoon ${ }^{12}$ が家 族内に発生した肥満，性器発育不全，網膜色亲变 性怙よび知能障害を伴う4例を報告し，1920年，

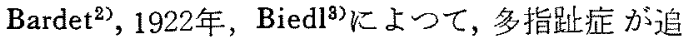
加され，今日では，肥満，網膜色素变性，知能障 害, 性器発育不全, 多指趾症等を主徵とする遗伝性 疾患とされている，Rossらは4，1956年迄に，約 300例之推定して未括り，本邦では，野村，佐々5 は1956年迄に約56例，狩野，昖岡 ${ }^{6)}$ は，1961年 に，過去10年間のみで約56例を，また，石川防は， 1971年 5 月迄に，179例を集めている. 従つて， 本症候群は，少ない疾患群ではあるが，必ずしも 極めて稀なるのとは云克ない。

本症候群の臨床症状については，各種の他疾患 との合併例が報告されている8．また，身体の奇形 屯合併して，心奇形，腎奇形，頭部奇形等が報告 されている，著者の経験した症例の様に，多飲，
多尿，多飲，糖尿等を始めとする糖代謝異常を伴 つたL-M-B症候群 ${ }^{9)}$ あ報告されているが，その大 部分は，空腹時血糖が正常であり，その $1 / 5$ に耐糖 能の低下が見られるといわれている。臨床症状に ついてみて見ると，L-M-B症候群の 6 主徵の発現 頻度は，以外飞少なく，4〜5主徵のbのが大部 分である。

L-M-B症候群の病因諭は，不明の点が多いが， 遗伝に基つく疾患である事は，疑いのないところ であるが，艺の遗伝形式については，判然としな

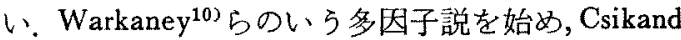
とMather ${ }^{11}$ のい5一因子説があり，そのいずれ に依るかは，今後の研究になたねばならない。

Ornsteen ${ }^{12)}$ は，指趾異常を除く症状は，発生学 的に網膜の原基である原始細胞，終脳，間脳がい ずれも前脳からら生ずるので，その発生期の障害 が, 絧膜色素変性, 知能障害, 肥満, 性器異常を 惹起すると考えている。また，Panse ${ }^{18)}$ は，間脳 と四肢末端形成との関係論し，間脳からの誤つ た発育刺激が指趾異常を起こすのではないかと述 べている

本症候群は，病理剖検例が極めて少なく，1967 年迄に，M.C. Laughlin ${ }^{14)} か ゙ ， 18$ 例をまとめたに すぎず，本邦では，方ずかに，2 例占116)のみであ る. それらの剖検所見であるが，内分泌藏器の变 化は少なく，脳に和いても，一定の变化が認めら れていないようである。しかし，視床下部，間脳 腫瘍で，性腺機能異常，肥満，尿崩症などの症状 を呈することは周知の事実であり，妊娠動物に種 種の外因や化学物質を与えると，間脳の異常と共 に，脳奇形之指趾異常を生ずるといら実験的事実 も㐫り，発生学的に説明可能なことなど考充合わ せると，なんらかの間脳異常が関与している事は 疑いないところであるら。

著者の経験した症例は，従兄姝同志の血族結婚 であり，母方の家族に同様な症状を示す症例があ る事と, 肥満, 網膜色素变性, 多指趾症, 知能障害 と，いわ妕る，L-M-B症候群の 5 主徵が揃つてい ぞ. その他，合併症として，頭部奇形 (荅状様)， 
空腹時高血糖と高度の耐糖能異常, 多量の尿糖排 泄があり，性器発育は，外観上，正常であつた が，基礎体温の一相性などが存在していた。この 様な点から，高度の楉尿病状態を伴つたL-M-B症 候群といらことで，極めて與味ある症例と考兄 る。しかも，著者の経験した症例が興味あると思 えるのは，insulinを用いて楉尿病状態が良好に， コントロールされ，経口抗榶㽷病薬で，置換され ると，多领，多尿，低比重原を，主訴として来る 様になり，いわゆる，尿崩症状態を示して来たこ とである。

尿崩症は，下垂体後葉のVasopressin，すなわち，

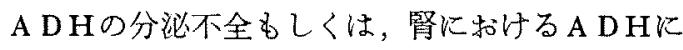
対する反応性の低下により生ずるものと理解され ており，ADHについては，かなり詳しい知見が 得られている。尿崩症の原因については，さまざ まであるが，大別して，特発性尿崩症，続発性ま たは症候性尿崩症およびその他のものに分けられ る.これらと鑑別を要するものに心因性多飲症が ある．心因性多领症は，間脳の障害による口渴と 多飲が第一次でその結果，多尿を来たするので， 下垂体性尿崩症が，A D H穴による多尿が第一 次である点と異なる.

著者の 経験したL-M-B症候群は，その病因論 に, 間脳障害が考学られるし，周知の様に，間脳 には，自律神経系の中枢があり，心因性尿崩症を 来たす可能性も充分にあるので，鑑別主る必要が とくにある.他方，視床下部には，睡眼の中枢の 存在が知られており，その障害で，激しい空腹 感, 不稳, 興奮, 精神神経障害を伴い, 周期的に 起こる赀眠発作を，3〜 6 カ月ごとに起こし，2 〜3 日間持続するというKleine-Levin症候群も知 られているので, 狂暴性, 一過性の频眠発作，脳 波上alpha波の消失などが，本症例で見られた点

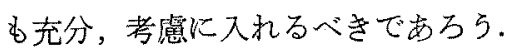

また，尿崩症を，心因性多飲症から鑑別する事 は，必ずしも容易でないが，口渴テスト， pitressinテスト, Carter-Robbinsテスト等を試み，鑑別の 根掩とすべきであるとされている.しかし，これ
らの試験て鑑別されない事も多く, de Wardener ${ }^{17)}$ は, もし, 脱水後尿比重が, Pitressinのみによつ て生ずる尿濃度よりも，高け机は，尿呩度が低く ても，A DHを分泌する能力は，正常であるとす べきとしているが，脱水後の尿濃度がPitressin のみによつて生ずる尿濃度よりも低ければ，たと え，到達した尿濃度が高くても，A D Hの分泌能 は異常であると考えている.しかし，この両者， すなわち，尿崩症と心因性多领症を混同するほど 重症であれば，重症の精神病的障害を鈢成する要 素，すなわち，重大な人格または，行動の障害を 伴う神経症的徵候を明らかにし得るのが普通であ るとも結論している.

著者らの経験した症例では，すでに述べた様 に，口渴テスト，Pitressinテスト, Carter-Robbins テストなどの試験では，下垂体尿崩症の診断は， 決定し難いが， de Wardenerのいらテスト，寸な わち，口渴テストとPitressinテストとを組み合わ せて行なつてみると，尿比重は，後者の方か上昇 し, A D Hの分泌能は異常であると思える.

\section{糖尿病と尿崩症の合併について}

両者の合併例については，1866年，Senatorの 報告以来，約60例の報告裙があるにすぎない，そ して，必ずしも，容易でないが，これを，一元的 に説明しょらとの試みがなされている。すなお ら，Halesらは，視床下部腹側中央核の破壊によ $り$, hyperinsulinism打よびhyperglycemia 観察 しており，間脳腫瘍が，時として，糖尿病を伴う ものである事も報告されており，Strieckはイヌで Ransonはサルで，視床下部破壊により，糖尿病の 発生することも報告している。一方, 視床下部腹 側内側核の破壊で, 肥渾と食欲亢進が起こり，腹 側内側核の破壞むたは，刺激で，外側にある食欲 中枢が機能的に影響され得ることも考えられてい る。をた，臨床的にも，脳炎などの後遺症として 著明な肥満が起こつた様な症例で, 腹内側核, 旁 室核，視床上核などの神経細胞の減少をみたとの 報告むある。この嵄に，間脳は，自律神経を介し て血糖を調節し，また，間脳は，下垂体を介して 
成長ホルモン，A C T H甲状腺刺激ホルモンなど を分泌することによつてる，血精調節をはかるの で，間脳一下垂体系は，血糖調節の最高中权とも 考兄られている。結局，尿崩症と糖尿病の合併の 病因論的接点を，間脳一下垂体系の障害に求める ことが出来るように思われる。

以上の様に考えてみると，本症例は，L-M-B症 候群，糖尿病状態，尿崩症状態，狂暴性，嗜眠発 作など，すべての症状が，一連の広範な間脳性の 障害として理解し得る様に思われる。ささ本症 例の治療であるが，L-M-B症候群は，それ自体が 遗伝性の発育異常であり，治療の対象とは，なり 得ないであるう．糖尿病ならびに尿崩症に対して は，治療を行ならべきであるう。すなわら，著者 の症例では, 糖永病に対しては, 初期には, insulin 療法を行なつたが，後には，経口抗糖尿病薬への 転換が可能となり，尿崩症が明らかになつた時点 からは，抗利尿作用があるといわれるP $607^{193}$ 用い，一時的に尿量の減少を認めることが出来 た. しかし，thiazide采利尿薬には，期待した活 どの効果が認められなかつた。

\section{結 語}

肥満, 網膜色素変性, 知能障害, 多指趾症, 血 族結婚を伴つた26才の女性に，Laurence-Moon-
Biedl症候群という䛦断を下したが，この症例で は，同時に，糖尿病，尿崩症，Kleine-Levin症候 群などの多彩な合併が認められたので，誠に，興 昧ある症例之考克，文献的考察をも加光て報告し た.

\section{文献}

1) Laurence, J.Z. and R.C.Moon.: Brit. Ophth. Rev. 2: 32, 1866. -2) Bardet, G.: Univ. Paris Thesis. 470: 170. 1920. -3) Biedl, A.: Deutsch. Med. Wchschr. 48: 1630, 1922. -4) Ross, C.F. L., Crome and D.Y. Mackenzie.: J. Path. Bact. 72：161，1956. 一5) 野村, 在々：内科，2：150, 1957,一6) 特野，松岡：小児科紀要， $7: 69$, 1961，一7) 石川：日内会誌，61:53，1972，一8) 三宅，井村：日本臨床， $20: 373 ， 1962 ，-9)$ 井 出，金子，塩沢：日内全誌，43:918，1955。一-10) Warkaney. J., G.S. Fruaenberger and A.G. Mitchel.: Amer. J. Dis. Child. 53: 455, 1937.

11) Csik. L. and K. Mather. Ann Euge. (Lond.) 8: 128, 1938. -12) Ornsteen. A.M.: Amer. J. Med. Sc. 183: 256, 1932. -13) Panse. F.: Allg. Zschr. Psych. 112: 106, 1939. -14) M.C. Laughin 代謝, 8:488,1972, 臨时增刊. 一15) 薄 井5：日内会誌, $58: 184,1969$. 一16) 浅野与： Medical, J. of Shinshu Univ. 8. (I-2) -17) Barlow, E.D. and de Wardener, H.E.:compulsive and water drinking. Quart. J. Med. 28: 235, 1959. - 18) Bretz, G.W.: Amer. J. Med. 4: 398, 1970. -19) 浦壁的：内科, $28: 58$, 1971. 